- FINANSE I PRAWO FINANSOWE.

- Journal of Finance and Financial Law •

Czerwiec/June 2017 • vol. 2(14): 115-129

http://dx.doi.org/10.18778/2391-6478.2.14.09

\title{
NIEPEŁNOSPRAWNOŚĆ A ZAGROŻENIE WYKLUCZENIEM FINANSOWYM
}

Anna Warchlewska

Dr, Katedra Pieniądza i Bankowości Uniwersytet Ekonomiczny w Poznaniu

\section{Streszczenie}

Celem artykułu jest diagnoza problemu wykluczenia finansowego wśród osób z niepełnosprawnością. Przedmiotem niniejszego opracowania jest przedstawienie działań sektora bankowego mającego na celu wyrównywanie szans dostępu do usług bankowych oraz krytyczna ich analiza. Na kanwie regulacji prawnych i działań Związku Banków Polskich przedstawiona została sytuacja osób z niepełnosprawnością oraz zwrócono uwagę na istotę wykluczenia finansowego. Podstawą do analizy były dostępne źródła literatury oraz wyniki badań własnych, które pozwoliły wskazać dalsze kierunki badań. Struktura artykułu jest podporządkowana celowi badawczemu.

Słowa kluczowe: wykluczenie finansowe, osoby z niepełnosprawnością, prawa człowieka, dobre praktyki bankowe, sektor bankowy.

JEL Class: D18, G02, G21, J14. 


\section{WPROWADZENIE}

Intensyfikacja działań instytucji publicznych, prywatnych i non-profit w zakresie minimalizacji skali wykluczenia finansowego wynika z istoty pomijanego wcześniej problemu i ewentualnych, negatywnych konsekwencji pozostawania poza sektorem finansowym. Izolacja finansowa wynikająca $\mathrm{z}$ barier i utrudnionego dostępu do usług finansowych dotyczyć może wszystkich grup społecznych. Spektrum czynników warunkujących problem jest szeroki, od samowykluczenia po czynniki ekonomiczne, społeczno-psychologiczne, demograficzne, aż po fizyczne bariery dostępu. Mając na względzie niwelowanie przeszkód, sektor finansowy, a szczególnie banki jako instytucje zaufania publicznego, powinny kierować się ideą absolutnej równości i sprawiedliwości społecznej [Zboroń 2004: 96-97]. Wydaje się ona mało realistyczna, choć w swoim założeniu stanowi cel dla wszystkich działających w imię dobra społecznego. Jako instytucje nastawione zgodnie z profilem działalności również na zysk, idea zapewnienia równego dostępu do usług finansowych jest nierealna, po pierwsze ze względu na wymagania formalne stawiane przez banki (np. wnioski o kredyty, pożyczki), po drugie ze względu na klasyfikację klientów na segmenty odpowiadające ich potrzebom.

Interdyscyplinarność problematyki wykluczenia finansowego [szerzej: Warchlewska 2015b] wyłania grupy narażone na wykluczenie finansowe, m.in. osoby o niskich dochodach, kobiety, bezrobotni, osoby starsze i młodzież niepracująca, rodzice samotnie wychowujący dzieci, osoby niepracujące z powodu choroby, imigranci, osoby zamieszkujące tereny słabo zurbanizowane i obszary wiejskie oraz niewątpliwie osoby z niepełnosprawnością.

Zgodnie z założeniami Związku Banków Polskich [ZBP, 2016b, dostęp: 28.01.2017] dotarcie do blisko 5 milionów osób z niepełnosprawnością ${ }^{1}$, czy też mówiąc szerzej - osób ze szczególnymi potrzebami w zakresie obsługi - powinno przyczynić się do koncentracji działań w zakresie jakości obsługi. Praktyka bankowa pokazuje, iż jest to zadanie trudne w realizacji. Bariery komunikacyjne podczas kontaktu osobistego z pracownikiem banku, brak kontaktu telefonicznego w nagłych sytuacjach, niezrozumienie treści umów bankowych, niewystarczające przygotowanie personelu do obsługi osób $\mathrm{z}$ niepełnosprawnością, to tylko zarys trudności. Brak aktywności finansowej osób, których ograniczenia obejmują sferę sensoryczną, fizyczną i psychiczną przyczyniać się może do wykluczenia finansowego i w konsekwencji wykluczenia społecznego, choć związek obu tych wykluczeń może przybierać kierunek odwrotny. Bank centralny w ramach programów minimalizacji wykluczenia finansowego rozumianego jako trudności, z jakimi borykają się jednostki w dostępie do usług finansowych,

${ }^{1}$ Ze względu na różnorodność podejść w definiowaniu, dla przejrzystości wywodu autorka przyjmuje opis osób z dysfunkcjami jako osoby z niepełnosprawnością, za: Galasiński [2013: 3-6]. 
wspiera edukację ekonomiczną wśród osób w wieku senioralnym oraz osób młodych do 35 roku życia jako grupy szczególnie narażone na wykluczenie ze świata finansów. Wydaje się jednak, że osoby z niepełnosprawnością w działaniach edukacyjnych, promocyjnych, szkoleniowych są pomijane, choć powinny stanowić równoległą grupę docelową w integracji finansowej.

Celem niniejszego opracowania jest diagnoza problemu wykluczenia finansowego wśród osób z niepełnosprawnością. Pomijając krótkie artykuły sygnalizujące problem, to tematyka osób z niepełnosprawnością na rynku usług finansowych podnoszona jest stosunkowo rzadko. W opracowaniu, skoncentrowano się na dostępie do usług bankowych i krytycznej analizie zadeklarowanych działań sektora bankowego w zakresie obsługi osób z dysfunkcjami. Struktura artykułu została podporządkowana powyższemu celowi i składa się z trzech części. Pierwsza część nakreśla sytuację osób z niepełnosprawnością na rynku usług bankowych poprzez obowiązujące rozwiązania prawne i działania instytucji nadzorujących sektor bankowy. Część druga przedstawia skalę wykluczenia finansowego, szczególnie wśród grup narażonych na ten problem. W części trzeciej dokonana zostanie krytyczna analiza implementacji Dobrych praktyk obstugi osób z niepetnosprawnością. Konkluzję niniejszego opracowania stanowią rekomendacje dla sektora bankowego w zakresie niwelowania barier w dostępie do usług bankowych. W nawiązaniu do celu głównego opracowania jako hipotezę badawczą przyjęto stwierdzenie, że brak aktywności finansowej osób $\mathrm{z}$ niepełnosprawnością to problem o podłożu informacyjnym, prawnym, instytucjonalnym, ekonomicznym i społecznym.

\section{ZAANGAŻOWANIE SEKTORA BANKOWEGO W POMOC OSOBOM Z NIEPEŁNOSPRAWNOŚCIA}

Dla oceny sytuacji osób z niepełnosprawnością na rynku usług bankowych - bez barier - ważna jest odpowiedź na pytanie, na ile regulacje prawne sprzyjają ich aktywności w analizowanym obszarze. $Z$ dużą dozą optymizmu należy dostrzec prawne i teoretyczne dostosowanie środowiska bankowego do obsługi osób z niepełnosprawnością [Ploch 2009: 2-3]. Implementacja przepisów prawnych i przyjętych rozwiązań systemowych wymaga intensyfikacji działań i realnych efektów w sektorze bankowym.

Likwidacja barier pomiędzy pełnosprawnymi a osobami z niepełnosprawnością należy do obowiązków państwa prawa, czego odzwierciedleniem są stosowane uwarunkowania prawne na gruncie krajowym i międzynarodowym. Prawa konsumentów zawarte są m.in. w Konstytucji RP z dnia 2 kwietnia 1997 r. [Dz.U. 1997, nr 78, poz. 483 ze zm.], Ustawie z dnia 27 sierpnia 1997 r. o rehabilitacji zawodowej i społecznej oraz zatrudnianiu osób niepełnospraw- 
nych [Dz.U., nr 226, poz. 1475 ze zm.] oraz Karcie Praw Osób Niepełnosprawnych [M.P. 1997, nr 50, poz. 475]. Prawo międzynarodowe zwraca szczególną uwagę na przeciwdziałanie wykluczeniu społecznemu, wyrównywanie szans i równe traktowanie osób z niepełnosprawnością. Prawa konsumentów skodyfikowane zostały m.in. w Rezolucji 48/96 nt. Standardowych Zasad Wyrównywania Szans Osób Niepełnosprawnych, która została przyjęta 20 grudnia 1993 r. podczas 48. Sesji Zgromadzenia Ogólnego ONZ [Dz.U. 2012, poz. 1169], Konwencji Praw Osób Niepełnosprawnych [Rezolucja Zgromadzenia Ogólnego ONZ A/RES/61/106 z dnia 13 grudnia 2006 r.], Karcie Praw Podstawowych Unii Europejskiej [EUR-Lex C 326/391], Europejskiej strategii w sprawie niepełnosprawności 2010-2020 z dnia 15 listopada 2010 r. [Rzecznik Praw Obywatelskich 2011].

Ratyfikacja Konwencji Organizacji Narodów Zjednoczonych przez Polskę w 2012 r. była doniosłym aktem, normalizującym kompleksowo zagadnienia związane z niepełnosprawnością [Szreniawska 2012]. Zasadniczym jej celem jest ,popieranie, ochrona i zapewnienie pełnego i równego korzystania z praw człowieka i podstawowych wolności przez osoby z niepełnosprawnościami” [Dz.U. 2012 poz. 1169]. Jak stanowi Art. 9 Konwencji państwo powinno zapewnić pełny udział w życiu społecznym oraz dostęp do usług i obiektów powszechnie dostępnych osobom z niepełnosprawnością. Dostosowanie do standardów wyznaczonych przez Konwencję wiąże się z przezwyciężeniem barier komunikacyjnych, technologicznych oraz architektonicznych w sektorze bankowym [ZBP 2016b, dostęp: 28.01.2017].

Każdy rodzaj niepełnosprawności stwarza odmienne problemy. Jednym z największych wyzwań stawianych przed sektorem bankowym jest kompleksowość obsługi, tak, aby klienci z dysfunkcjami mogli w pełni korzystać z usług bankowych na równych prawach z klientami sprawnymi. Wszechstronność działań dostosowawczych niestety jest rzadkością w Polsce. W tym celu Związek Banków Polskich promuje działania na rzecz osób z niepełnosprawnością, powołując Zespół ds. obsługi osób $\mathrm{z}$ niepełnosprawnościami, który podejmuje inicjatywy we współpracy z Fundacją Integracja. Zaangażowanie ZBP przyczyniło się do przygotowania zestawu dokumentów [ZBP 2016a, dostęp: 25.03.2017]: banki.

a) II edycja Dobrych praktyk obsługi osób z niepełnosprawnościami przez

b) Folder Bank bez barier.

c) Folder Savoir-vivre wobec osób z niepełnosprawnością.

Dobre praktyki obstugi osób z niepetnosprawnościami przez banki to swoisty kodeks nawołujący świat biznesu do prowadzenia działalności w przyjazny sposób, z większą wrażliwością społeczną. Zawiera szczegółowe zalecenia dla placówek bankowych, w jaki sposób postępować podczas codziennej obsługi 
klientów z dysfunkcjami słuchu, mowy, ruchu i niepełnosprawnością intelektualną. Dokument zwraca uwagę na zasady prowadzenia komunikacji z wykorzystaniem bankomatu, Internetu, bankowości mobilnej i call center. Autorami opracowania są przedstawiciele banków komercyjnych, Związku Banków Polskich oraz Narodowego Banku Polskiego, co niewątpliwie wpłynęło na jego wysoki poziom merytoryczny i jego kompleksowe ujęcie [ZBP 2014, dostęp: 26.03.2017]. Przewodnik Savoir-vivre wobec osób z niepełnosprawnościa powstał $\mathrm{z}$ inicjatywy Fundacji Integracja. Podpowiada on w bardzo przystępny i czytelny sposób, jak zachowywać się w kontaktach $\mathrm{z}$ osobami z niepełnosprawnością na co dzień. Wątpliwość z punktu widzenia codziennych czynności w banku, budzi sama zawartość Przewodnika. Wydaje się on być prostym, aczkolwiek zdaniem autorki, ubogim zbiorem podpowiedzi dla czytelnika. Treści tam zawarte niewątpliwie mogą być pomocne dla pracowników banku w obsłudze, choć myśląc o przewodniku powstającym pod patronatem ZBP, przedstawienie najczęstszych sytuacji i realizowanych transakcji $\mathrm{w}$ banku, powinno stanowić motyw wiodący [Integracja 2016].

Narodowy Bank Polski poprzez inicjatywę Bank Dostępny przybliżył problemy z jakimi borykają się osoby z niepełnosprawnością $\mathrm{w}$ banku. Poprzez formę konkursu skierowaną do 14 banków (43 oddziały i filie) wyłoniono najlepsze oddziały, które zorganizowały najlepszą obsługę osób z niepełnosprawnościami. Niniejsza inicjatywa dodatkowo miała na celu doprecyzowanie standardowych procedur obsługi klienta [Narodowy Bank Polski 2013].

\section{ZAGROŻENIE WYKLUCZENIEM FINANSOWYM}

Konstatując działania Narodowego Banku Polskiego zmierzających do minimalizowania marginalizacji finansowej m.in. wśród osób powyżej 55 roku życia, wskazać należy pozytywny obraz prowadzonej polityki odpowiedzialnego biznesu i troski o aktywność we wszystkich grupach społecznych. Niestety obserwuje się zachowawczość w działaniach wspomagających środowisko osób $\mathrm{z}$ dysfunkcjami. Sytuacja na polskim rynku oraz prawo bankowe nie zawiera mechanizmów ułatwiających dostęp do podstawowych usług bankowych osobom najbardziej zagrożonym wykluczeniem finansowym [Warchlewska 2015a: 39-49]. Biorąc pod uwagę czynniki ekonomiczne, warunkujące dostęp do usług bankowych, poprawić ten stan powinna implementacja Dyrektywy Parlamentu Europejskiego i Rady 2014/92/UE z dnia 23 lipca 2014 r. [EUR-Lex L 257/214] w sprawie porównywalności opłat związanych z rachunkami płatniczymi, przenoszenia rachunku płatniczego oraz dostępu do podstawowego rachunku płatniczego, na mocy, której dostep do rachunku podstawowego pozwoli konsumen- 
tom na wykonanie podstawowych, najbardziej popularnych ustug platniczych (w tym dokonywanie platności internetowych) [KNF, Informacja..., dostęp: 03.04.2017].

Osoby pełnosprawne oraz z osoby niepełnosprawnością mogą być narażone na ekskluzję finansową w sześciu obszarach (rysunek 1). Głównym z nich jest wykluczenie płatnicze (bankowe). Brak aktywności płatniczej może prowadzić do pozostałych wykluczeń. Wskazany obszar cechuje m.in. brak rachunku bankowego, brak płatności bezgotówkowych, brak wykorzystania zdalnych kanałów dostępu do konta. W niniejszym artykule ten obszar będzie stanowił główne źródło rozważań.

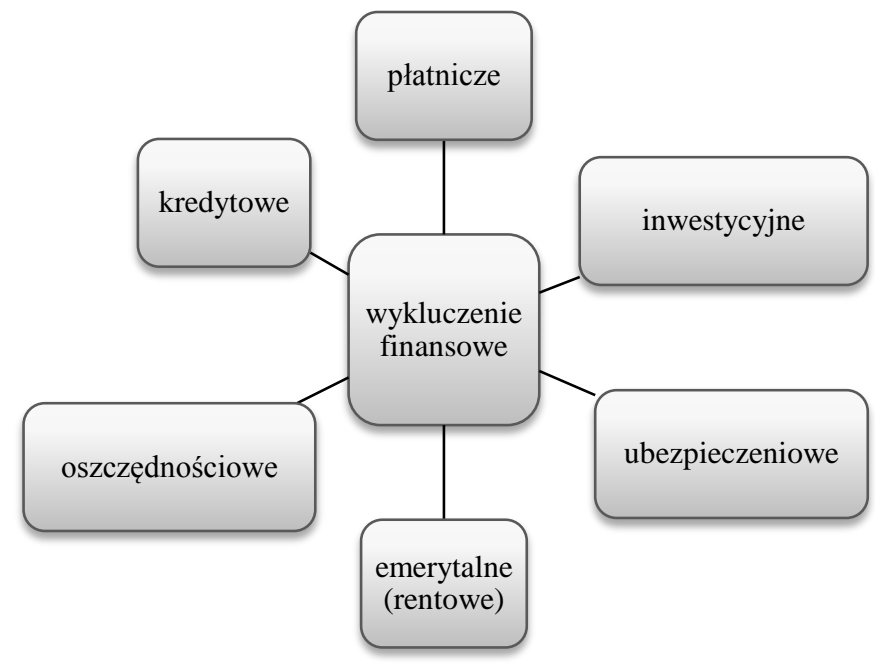

Rysunek 1. Obszary wykluczenia finansowego

Źródło: Koźliński [2010, dostęp: 29.03.2017].

Wykluczenie finansowe w obszarze oszczędności diagnozuje się poprzez brak nadwyżki finansowej, czego efektem może być brak nawyku oszczędzania. Znikoma aktywność na rynku kredytowym to przede wszystkim efekt negatywnej historii kredytowej lub braku potrzeby korzystania z zewnętrznych źródeł finansowania. Wykluczenie finansowe dotyczy również obszaru ubezpieczeń, co wynikać może z ograniczonych zasobów społeczeństwa. Wśród powodów wykluczenia w obszarze inwestycji należy wskazać brak zasobów, wiedzy oraz znikomą awersję do ryzyka. Niedostosowanie produktów do najstarszej grupy wiekowej i osób otrzymujących świadczenia rentowe (w tym osoby z niepełnosprawnością) stanowi ostatni obszar wykluczenia ze świata finansów. 
Problem marginalizacji finansowej przybiera różne formy. W zależności od przyczyn warunkujących wykluczenie wyróżniamy [Kempson i Whyley 2010: 10]:

a) wykluczenie o podłożu geograficznym (zbyt mała liczba placówek, słabo rozwinięta infrastruktura płatności bezgotówkowych),

b) wykluczenie ze względu na dostępność (brak dostępu do bankowości elektronicznej, brak zdolności kredytowej, nieodpowiedni wiek klientów),

c) wykluczenie ze względu na warunki (niedopasowanie produktów i usług do potrzeb klienta),

d) wykluczenie ze względu na cenę (zbyt wysokie opłaty i prowizje),

e) wykluczenie marketingowe (brak zainteresowania ze strony instytucji daną grupą społeczną),

f) samowykluczenie (dobrowolna rezygnacja z usług finansowych).

Warto zaznaczyć, że w przypadku osób z niepełnosprawnością wykluczenie ze względu na warunki, wykluczenie marketingowe i samowykluczenie może być diagnozowane częściej w stosunku do trudności na tle geograficznym, dostępności, czy ze względu na cenę. Dla osób z niepełnosprawnością istotniejsze od ilości placówek jest ich wyposażenie, swoboda poruszania się w niej oraz profesjonalna obsługa. Na wykluczenie ze względu na warunki niewątpliwie ma wpływ pomijanie przez sektor bankowy osób $\mathrm{z}$ dysfunkcjami w segmentacji klientów i niedopasowanie produktów do ich potrzeb, co łączy się z wykluczeniem na tle marketingowym. Konsekwencją napotykanych trudności logistycznych, barier mentalnych i komunikacyjnych w banku jest dobrowolna rezygnacja z usług finansowych.

Przyjmując wykluczenie finansowe jako odrębne zjawisko, można zdefiniować je jako problem pierwotny (brak możliwości korzystania z oferty finansowej) lub jako problem wtórny (konsekwencja wykluczenia w innym obszarze). W nawiązaniu do oceny, co jest przyczyną, a co skutkiem tej relacji, wykluczenie społeczne będzie traktowane jako przyczyna wykluczenia finansowego w sytuacji, gdy otoczenie społeczne jednostki determinuje jej zachowanie na rynku finansowym. Odzwierciedleniem takiej zależności jest schematyczne podejście do pieniądza osób o niskim poziomie wiedzy i świadomości finansowej. W kontekście analizowanej grupy docelowej mogą to być dodatkowo bariery komunikacyjne, architektoniczne. Wykluczenie finansowe można uznać za przesłankę (jedną z przyczyn wykluczenia społecznego) w sytuacji, kiedy osoba ubankowiona i aktywna finansowo, z braku źródła dochodu - wykluczenie osób z niepełnosprawnością z rynku pracy - nie może tej aktywności kontynuować i powoduje izolację społeczną jednostki. Obszerność posiadanej wiedzy, duża świadomość ekonomiczna pozostaje bez wpływu na negatywne konsekwencje (np. brak spłaty zobowiązań finansowych). Wobec powyższego, trudno jednoznacznie wskazać zależność przyczyna-skutek obu tych wykluczeń. 
Problematyka wykluczenia finansowego najczęściej analizowana jest w literaturze, wykorzystując miernik nieposiadania rachunku bankowego. Zdaniem autorki, wybór tego miernika pozwala relatywnie ocenić skalę zjawiska. Mierniki wskazane w punktach 1-8 dają podstawy do oceny ograniczeń, mogących być bezpośrednio lub pośrednio przyczyną braku rachunku bankowego. O słuszności takiego założenia świadczyć może wybór A. Alińskiej [2008: 153-166; 2011: 289-301] miary wykluczenia finansowego, jaką jest odsetek dorosłych mieszkańców Polski, którzy nie posiadają rachunku bankowego. W dostępnych materiałach źródłowych można wyróżnić szereg innych mierników wykluczenia finansowego już określonego [Maciejasz-Świątkiewicz 2013: 77-78]:

1) liczba osób nieposiadających pożyczki odnawialnej,

2) liczba osób nieposiadających kart kredytowych,

3) liczba ogłoszonych upadłości konsumenckich,

4) liczba zgłoszeń do baz nierzetelnych klientów,

5) liczba osób zalegających w spłacie zobowiązań,

6) liczba osób nieposiadających ubezpieczenia,

7) liczba osób nieposiadających oszczędności,

8) liczba osób niedokonujących transakcji bezgotówkowych.

Powyższe mierniki wykluczenia finansowego odnoszą się do obszarów wykluczenia finansowego. Literatura definiuje również mierniki wykluczenia finansowego potencjalnego, jak np. liczba osób bezdomnych, osób z niepełnosprawnością, osadzonych, na granicy ubóstwa, nisko wykształconych, bezrobotnych, korzystających ze świadczeń socjalnych. Wydaje się jednak, że powyższe mierniki jako wskaźniki oceny skali zjawiska mogą być stosowanie błędnie (zamiennie), między innymi dlatego, iż np. osoby z niepełnosprawnością nie muszą być wykluczone finansowo. Na ważność opracowania listy uznanych mierników dla celów międzynarodowych analiz porównawczych wskazuje M. Maciejasz-Świątkiewicz [2013: 77-78]. Interdyscyplinarność problematyki wykluczenia finansowego może pomóc wskazać grupy zagrożone wykluczeniem finansowym z powodów socjalnych i społecznych dla celów profilaktyki i oceny głębokości zjawiska w analizowanych obszarach ${ }^{2}$.

Poziom wykluczenia finansowego w Polsce ulega stopniowemu zmniejszeniu (zob. tab. 1). Trudność w ocenie tempa zmian wynika z przyjętych metodologii. Badanie NBP z 2009 r. przeprowadzono wśród dorosłych respondentów, natomiast badanie Banku Światowego w 2014 r. przedstawia odpowiedzi respondentów powyżej 15 roku życia. Prognozy poziomu wykluczenia finansowego na lata 2020-2025 sporządzone przez Deloitte uznać należy za optymistyczne i jednocześnie realne. Po pierwsze, poddając analizie problem na gruncie mniejszych jednostek terytorialnych np. województwa wielkopolskiego i aglomeracji

${ }^{2}$ Fragment oparty został na rozprawie doktorskiej A. Warchlewskiej Wykluczenie finansowe jako wyzwanie dla sektora bankowego (na przykładzie aglomeracji poznańskiej). 
poznańskiej obserwuje się zmniejszenie skali zjawiska. Po drugie, implementacja Dyrektywy Parlamentu Europejskiego i Rady 2014/92/UE dotyczącej dostępu do podstawowego rachunku płatniczego do 8 sierpnia 2018 r. wpisuje się w strategię minimalizacji wykluczenia finansowego.

Niestety powyższe dane źródłowe (na moment tworzenia niniejszego opracowania) nie podają skali problemu wykluczenia finansowego wśród osób z niepełnosprawnością. Tylko dane z 2003 r. Narodowego Banku Polskiego w syntetyczny sposób przedstawiają, iż osoby z niepełnosprawnością i osoby starsze stanowią około 75\% ogółu [Narodowy Bank Polski 2003: 5]. W badaniu na terenie aglomeracji poznańskiej skoncentrowano się na rozpoznaniu skali problemu, bez ukierunkowania się na grupy zagrożone wykluczeniem finansowym. Osoby z niepełnosprawnością zostały rozpoznane po udzieleniu odpowiedzi na pytanie o posiadaniu orzeczenia o niepełnosprawności. $\mathrm{W}$ badaniu drogą ankietyzacji wzięło udział 492 respondentów, w tym 40 osób z orzeczeniem o niepełnosprawności. Wśród tej grupy 13 osób nie posiadało rachunku bankowego (wskaźnik wykluczenia finansowego wykorzystany w badaniu). Na podstawie pozyskanych danych nie można zweryfikować skali zjawiska ze względu na zbyt małą próbę. Zastany materiał źródłowy wskazuje lukę w opisie proble$\mathrm{mu}$, co stać się powinno przedmiotem dalszych prac badawczych.

Tabela 1. Wykluczenie finansowe w Polsce (2009-2025)

\begin{tabular}{|c|c|c|c|}
\hline \multicolumn{4}{|c|}{ Polska } \\
\hline $\begin{array}{c}2009 \text { r. } \\
(>18 \text { roku życia })\end{array}$ & $\begin{array}{c}2014 \text { r. } \\
(>15 \text { roku życia })\end{array}$ & $\begin{array}{c}2020 \mathrm{r} . \\
\text { prognoza Deloitte } \\
\text { z } 2012 \mathrm{r} .\end{array}$ & $\begin{array}{c}2025 \text { r. } \\
\text { prognoza Deloitte } \\
\text { z } 2012 \text { r. }\end{array}$ \\
\hline $77 \%$ - ubankowieni & $78 \%$ - ubankowieni & $78 \%$ - ubankowieni & $82 \%$ - ubankowieni \\
\hline $\begin{array}{l}23 \%-\text { wykluczeni } \\
\text { finansowo }\end{array}$ & $\begin{array}{l}22 \%-\text { wykluczeni } \\
\text { finansowo }\end{array}$ & $22 \%$ - wykluczeni finansowo & $\begin{array}{l}18 \%-\text { wykluczeni } \\
\text { finansowo }\end{array}$ \\
\hline \multicolumn{4}{|c|}{ Ubankowienie według województw - 2012 r. (>15 roku życia) } \\
\hline$>80 \%$ & $71-80 \%$ & $61-70 \%$ & $<61 \%$ \\
\hline wielkopolskie & $\begin{array}{l}\text { kujawsko-pomorskie, } \\
\text { łódzkie, śląskie, } \\
\text { opolskie }\end{array}$ & $\begin{array}{l}\text { dolnośląskie, zachodniopo- } \\
\text { morskie, pomorskie, warmiń- } \\
\text { sko-mazurskie, mazowieckie, } \\
\text { lubelskie, świętokrzyskie, } \\
\text { małopolskie }\end{array}$ & $\begin{array}{l}\text { lubuskie, podlaskie, pod- } \\
\text { karpackie }\end{array}$ \\
\hline \multicolumn{4}{|c|}{ Aglomeracja poznańska - 2014 r. (>18 roku życia) } \\
\hline \multicolumn{4}{|c|}{$91 \%$ - ubankowieni } \\
\hline \multicolumn{4}{|c|}{$9 \%$ - wykluczeni finansowo } \\
\hline
\end{tabular}

Źródło: opracowanie własne na podstawie: Polska: 2009 - Koźliński [2013: 22]; 2014 - The World Bank [2014, dostęp: 21.04.2017]; 2020/2025 - Deloitte [2012: 5, dostęp: 29.03.2017]; Ubankowienie według województw - Deloitte [2012: 14, dostęp: 29.03.2017]; Aglomeracja poznańska - badanie własne przeprowadzone w okresie kwiecień 2014-czerwiec 2014, $\mathrm{N}=492$. 


\section{DOBRE PRAKTYKI BANKOWE A RZECZYWISTOŚĆ}

Szczególne zalecenia Związku Banków Polskich dotyczące obsługi osób z różnymi dysfunkcjami wynikają z przyjętej drugiej edycji dokumentu Dobrych Praktyk, który został zaktualizowany i uzupełniony w stosunku do pierwszej edycji wydanej w 2012 r. Założenia, choć w teorii słuszne i ważne dla ochrony praw konsumentów z niepełnosprawnością, w praktyce dostrzec należy całkowity brak implementacji założeń lub zbyt wolne zmiany w obsłudze po stronie pracowników banków (tab. 2).

Tabela 2. Wybrane dobre praktyki ZBP i ich implementacja

\begin{tabular}{|c|c|}
\hline Założenia ZBP & Implementacja założeń - praktyka bankowa \\
\hline \multicolumn{2}{|c|}{ Dysfunkcja słuchu (ubytek słuchu powyżej $90 \mathrm{~dB}$ ) } \\
\hline $\begin{array}{l}\text { Przekazywanie osobie z dysfunkcją słuchu infor- } \\
\text { macji pisemnie w oddziale poprzez zapisywanie na } \\
\text { karteczkach }\end{array}$ & $\begin{array}{l}\text { Brak możliwości zablokowania, zastrzeżenia kart } \\
\text { płatniczych telefonicznie. Wymagana konieczność } \\
\text { wizyty w oddziale }\end{array}$ \\
\hline $\begin{array}{l}\text { Odczytywanie przez osobę z dysfunkcją słuchu } \\
\text { informacji z ust mówiącego i otrzymywanie odpo- } \\
\text { wiedzi na karteczkach i w formie gestów }\end{array}$ & $\begin{array}{l}\text { Nieprawidłowe oświetlenie, zbyt szybka obsługa } \\
\text { klienta w niedostosowanym pomieszczeniu. Brak } \\
\text { zrozumienia składni języka polskiego }\end{array}$ \\
\hline $\begin{array}{l}\text { Komunikacja w języku migowym (Polskim Języku } \\
\text { Migowym lub jego zagranicznym odpowiedniku) }\end{array}$ & $\begin{array}{l}\text { Brak możliwości wizyty ad hock w banku z tłuma- } \\
\text { czem Języka Migowego, znikoma możliwości } \\
\text { tłumaczeń na żywo on-line }\end{array}$ \\
\hline \multicolumn{2}{|c|}{ Dysfunkcja wzroku } \\
\hline $\begin{array}{l}\text { Możliwość złożenia podpisu z wykorzystaniem } \\
\text { „ramek”, wyposażenie oddziałów w lupy do od- } \\
\text { czytu umów przez klientów }\end{array}$ & $\begin{array}{l}\text { Trudności podczas realizacji transakcji w oddziale } \\
\text { i niezgodności złożonego podpisu z Kartą Wzoru } \\
\text { Podpisu }\end{array}$ \\
\hline $\begin{array}{l}\text { Brak jednoznaczności procedur po usunięciu } \\
\text { art. } 80 \mathrm{KC} \text {, który stanowił, iż jeżeli osoba niemo- } \\
\text { gąca czytać może złożyć oświadczenie woli na } \\
\text { piśmie, oświadczenie powinno być złożone } \\
\text { w formie aktu notarialnego }\end{array}$ & $\begin{array}{l}\text { W przypadku braku możliwości wizyty w banku } \\
\text { z osobą zaufaną nie zawsze można liczyć na odczy- } \\
\text { tanie jej treści wraz z załącznikami przez pracow- } \\
\text { nika. Niedostosowania zapisów umów na nośni- } \\
\text { kach elektronicznych lub ich brak }\end{array}$ \\
\hline \multicolumn{2}{|c|}{ Dysfunkcja ruchu } \\
\hline $\begin{array}{l}\text { Przystosowanie placówek do swobodnego poru- } \\
\text { szania się na wózku, o lasce, o kulach w oddziale } \\
\text { i przy bankomatach }\end{array}$ & $\begin{array}{l}\text { Usprawnienia wychodzące poza ramy prawa bu- } \\
\text { dowlanego. }\end{array}$ \\
\hline $\begin{array}{l}\text { Możliwość złożenia podpisu w formie tuszowego } \\
\text { odcisku palca, złożenie oświadczenia woli. Podpis } \\
\text { innej osoby poświadczony notarialnie na życzenie } \\
\text { klienta }\end{array}$ & $\begin{array}{l}\text { Brak szkoleń w tym zakresie dla pracowników } \\
\text { banku, brak wiedzy powoduje przeciąganie się } \\
\text { wizyt w banku lub konieczność powrotu }\end{array}$ \\
\hline \multicolumn{2}{|c|}{ Niepełnosprawność intelektualna } \\
\hline Zachowanie zasad etycznych pracownika banku & Nakłanianie do zakupu niezrozumiałych produktów \\
\hline $\begin{array}{l}\text { Zachowanie szczególnej ostrożności, czy osoba nie } \\
\text { została ubezwłasnowolniona częściowo lub całko- } \\
\text { wicie }\end{array}$ & $\begin{array}{l}\text { Brak możliwości } 100 \% \text { zweryfikowania podczas } \\
\text { rozmowy z pracownikiem banku }\end{array}$ \\
\hline
\end{tabular}

Źródło: opracowanie własne na podstawie: ZBP [2014, dostęp: 26.03.2017]. 
Najwięcej luk mogących wpływać pośrednio lub bezpośrednio na izolację finansową osób z dysfunkcjami zdiagnozowano podczas obsługi klienta w placówce banku oraz w kontakcie $\mathrm{z}$ bankiem poprzez zdalne kanały dostępu. Ustanowienie pełnomocnictwa w zakresie ogólnym, szczególnym czy jednorazowym, nie zawsze stanowi rozwiązanie łatwiejszego dostępu do usług bankowych. Instytucja pełnomocnictwa zakłada działanie na rzecz i w interesie mocodawcy przez wybranego i darzonego zaufaniem pełnomocnika. Udzielenie pełnomocnictwa do rachunku bankowego może ograniczyć działania osoby z niepełnosprawnością - mocodawcy do niezbędnego minimum, przy jednoczesnej realizacji uprawnień właściciela rachunku, wynikających z zawartej z bankiem umowy [Koszowski 2009, dostęp: 02.04.2017]. Niestety bariery dostępu nie znikają w przypadku konieczności zastrzeżenia karty płatniczej. Takiej czynności nie można scedować na pełnomocnika, gdyż karta nie jest jego własnością. Rozwiązanie powyższego problemu może nastąpić tylko osobiście w oddziale. Analiza założeń ZBP niestety przedstawia lukę w zapewnieniu kontaktu ad hock z udziałem tłumacza Polskiego Języka Migowego (kontakt bezpośredni, kontakt on-line). Konieczne jest zaplanowanie wizyty w konkretnym, wskazanym oddziale, odpowiednio wcześniej. Bariery dostępu do usług bankowych potęguje brak specjalistycznych szkoleń dla pracowników w zakresie obsługi klientów z dysfunkcjami, na każdym etapie obsługi. Niedostosowanie architektoniczne powoduje dalsze komplikacje w fizycznym dostępie do usług bankowych. Pomimo ciągłych prac nad modernizacją istniejących placówek, daleko do huraoptymizmu. Stanowi to wyzwanie dla sektora bankowego również ze względu na strategię likwidacji oddziałów i niepowstawania nowych $\mathrm{z}$ dostosowanymi rozwiązaniami. Instytucje zaufania publicznego stosując się do strategii odpowiedzialnego biznesu ukierunkowują działania nastawione na jakość. Z drugiej strony, strategia banków nastawiona na zysk to element biznesowego charakteru ich działalności, choć może ona odbiegać od działalności społecznej CSR, to nie powinna być odbierana negatywnie. Wątpliwość budzi jednak sprzedaż „za wszelką cenę” [Samcik 2013, dostęp: 02.04.2017], nawet osobom z niepełnosprawnością intelektualną, która nie zawsze jest świadoma podejmowanych decyzji. Fundamentalną zasadą obsługi klientów z niepełnosprawnością jak i pełnosprawnych jest przestrzeganie Kodeksu Etyki Bankowca. Przestrzeganie zawartych $\mathrm{w}$ nim zasad powinno przyczyniać się do obsługi w sposób nie naruszający interesy klientów, przekazując pełne i rzetelne informacje o produktach [ZBP 2013, dostęp: 02.04.2017].

Dążąc do weryfikacji postawionej hipotezy, jaką jest stwierdzenie, że brak aktywności finansowej osób $\mathrm{z}$ niepełnosprawnością to problem o podłożu informacyjnym, prawnym, instytucjonalnym, ekonomicznym i społecznym, przeanalizowano czynniki mogące mieć wpływ na izolację finansową osób z niepełnosprawnością $\mathrm{w}$ sektorze bankowym. Bariera informacyjna stanowi podwójny 
problem. Po pierwsze, wskazuje się na ważność i niestety znikomy charakter prowadzonych inicjatyw zwiększających wiedzę finansową wśród osób z niepełnosprawnością przez instytucje nadzorujące sektor bankowy (pomijając przewodniki/publikacje sygnalizujące problem). Po drugie, brak przygotowania merytorycznego pracowników banków do obsługi osób z dysfunkcjami dodatkowo wzmaga trudności natury informacyjnej. Analiza przepisów prawnych na gruncie krajowym i zagranicznym dotyczących zapewnienia dostępu do usług finansowych na równych zasadach nie budzi zastrzeżeń pod względem formalnym. Należy jednakże zachować sceptycyzm w stosunku do dostosowania sektora bankowego do standardów międzynarodowych w obszarze komunikacji, technologii i niwelowania barier technologicznych. Działania instytucjonalne [Florek-Łuszczki i Lachowski 2013: 480-484] podejmowane na rzecz osób z niepełnosprawnością powinny mieć charakter długofalowy. Bezpośrednią pomoc niosą instytucje publiczne m.in. PFRON, Biuro Pełnomocnika Rządu do Spraw Osób Niepełnosprawnych i organy pomocy społecznej. Niestety działania instytucji sektora bankowego ograniczają się do zaangażowania ZBP i NBP przede wszystkim w inicjatywy informacyjne. Brak szczegółowych wyników badań (na moment sporządzania opracowania) na temat skali problemu wykluczenia finansowego wśród osób z niepełnosprawnością w Polsce, nie pozwolił na analizę wpływu czynników ekonomicznych i społecznych na analizowany problem. Wskazuje się na potencjał badawczy, co wymaga dalszych prac w celu identyfikacji tychże czynników. Uznając istotność czynników o podłożu informacyjnym, instytucjonalnym i prawnym wobec braku aktywności finansowej - szczególnie na rynku usług bankowych - osób z niepełnosprawnością, uznać należy hipotezę za prawdziwą.

\section{PODSUMOWANIE}

Zagadnieniem badawczym w niniejszym opracowaniu było przedstawienie barier i zagrożeń w dostępie do usług finansowych wśród osób z niepełnosprawnością. W celu szczegółowej analizy podjętej problematyki dokonano oceny sytuacji osób z dysfunkcjami na gruncie przepisów prawnych unifikujących zagadnienia związane $\mathrm{z}$ niepełnosprawnością. Dokonano również przeglądu działań Związku Banków Polskich wynikających z systemowych założeń. Dążąc do realizacji celu głównego przedstawiono istotę problematyki wykluczenia finansowego oraz jego skalę w Polsce oraz na mniejszych terytorialnie obszarach. Brak prowadzonych badań w zakresie dostępu do usług bankowych wśród osób z dysfunkcjami sygnalizuje dalszy potencjał badawczy.

Rozważania oparte na krytycznej analizie Dobrych praktyk obstugi osób z niepetnosprawnościami przez banki pozwoliły zdiagnozować ograniczenia, które 
stanowią efekt zaniedbań sektora bankowego w obszarze polityki kadrowej, specjalistycznych szkoleń oraz zbyt wolne zmiany architektoniczne. Dążąc do wzmożonej aktywności osób z niepełnosprawnością na rynku bankowym i szerzej finansowym, niezbędna jest zmiana polityki kadrowej. Brak pracowników/tłumaczy języka migowego zatrudnionych bezpośrednio przez bank - pracodawcę, nie zachęca do wizyt w banku i utrudnia bieżący kontakt. W konsekwencji, nijak nie przystaje zasada sprawiedliwości i równości w dostępie do usług bankowych, czego przykładem może być obligatoryjność umówienia się na wizytę w banku na kilka dni wcześniej. Wzmożona koncentracja sektora bankowego na wdrażaniu koncepcji CSR wymusić powinna cykl szkoleń języka migowego.

Należy podkreślić, że obsługa osób z dysfunkcją wzroku wymaga zweryfikowania stanu posiadanej wiedzy przez pracowników, szczególnie front office oraz umiejętności radzenia sobie w sytuacjach niecodziennych, trudnych, bez konieczności konsultacji lub kolejnych wizyt klienta. Dla omawianej grupy społecznej może stanowić to trudność logistyczną i być powodem sytuacji stresującej.

Analiza dostępnych źródeł daje powody wnioskować, iż osoby z dysfunkcjami były wcześniej pomijane przez banki w dokonywanej segmentacji, nie stanowiąc grupy szczególnego zainteresowania, prawdopodobnie $\mathrm{z}$ punktu widzenia czysto finansowego i uprzedzeń społecznych. Brak wyposażenia w banku lub jego znikome ilości np. w pętle indukcyjne dodatkowo potęguje finansową izolację. Warto nadmienić, iż działania edukacyjne Narodowego Banku Polskiego powinny ukierunkować swoje działania na osobach $\mathrm{z}$ niepełnosprawnością. Wydaje się jednak, iż inicjatywa powinna być realizowana dwutorowo. Po pierwsze, poprzez warsztaty, szkolenia przeprowadzane bezpośrednio poprzez Ambasadorów we współpracy z opiekunami osób z niepełnosprawnością, skierowane do mniejszych społeczności lokalnych. Po drugie, bank centralny wraz z centralami banków powinni zweryfikować procedurę przeprowadzania szkoleń wstępnych, tak by przygotować pracowników do podstawowej obsługi bezpośredniej i telefonicznej wraz z procedurą szkoleń profesjonalnych (szkoleń dalszych), stanowiących element oceny pracownika i awansu.

Niniejsze opracowanie stanowi zarys i syntezę zdiagnozowanych trudności, jakie napotykają klienci z dysfunkcjami na rynku usług bankowych. Niewątpliwie jest to problematyka trudna w społecznym odbiorze, aczkolwiek należy podjąć dyskusję i aktywne działania na rzecz minimalizacji negatywnych skutków wrodzonych lub nabytych dysfunkcji. 


\section{BIBLIOGRAFIA}

Alińska A., 2008, Instytucje mikrofinansowe $w$ lokalnym rozwoju społeczno-gospodarczym, „Monografie i Opracowania” 558, Wydawnictwo SGH, Warszawa.

Alińska A., 2011, Skala ubankowienia polskiego spoleczeństwa, [w:] M. Dylewski, B. Filipiak (red.), „Zeszyty Naukowe”, nr 37, WSB, Poznań.

Deloitte, 2012, Doświadczenie klienta $w$ relacjach z bankami $w$ Polsce, https://bs.net.pl/upload/ File/Raporty/pl_doswiadczenia_klienta_w_relacjach_z_bankami_Deloitte_2012.pdf.

Dyrektywa Parlamentu Europejskiego i Rady 2014/92/UE z dnia 23 lipca 2014 r., EUR-Lex L $257 / 214$.

Florek-Łuszczki M., Lachowski S., 2013, Działania instytucjonalne na rzecz osób niepetnosprawnych, „Medycyna Ogólna i Nauki o Zdrowiu”, t. 19, nr 4.

Galasiński D., 2013, Osoby niepetnosprawne czy z niepetnosprawnościa??, „Niepełnosprawność - Zagadnienia, Problemy, Rozwiązania", nr IV (9), PFRON.

Integracja, 2016, Savoir-vivre wobec osób z niepetnosprawnościa, Wydawca Integracja. Stowarzyszenie Przyjaciół Integracji, Warszawa.

Karta Praw Podstawowych Unii Europejskiej, EUR-Lex C 326/391.

Kempson E., Whyley C., 2000, In or out? A literature and research review, „Consumer Research", nr 3.

KNF, 2017, Informacja o zasadach dostepu do podstawowego rachunku płatniczego, https://www.knf.gov.pl/Images/zasady_dostepu_do_podstawowego_rachunku_platniczego_t cm75-49835.pdf.

Konstytucja Rzeczypospolitej Polskiej z dnia 2 kwietnia 1997 r., Dz.U. 1997, nr 78, poz. 483 ze zm.

Konwencja o prawach osób niepełnosprawnych, sporządzona w Nowym Jorku dnia 13 grudnia 2006 r., Dz.U. 2012, poz. 1169.

Koszowski M., 2009, Prawnik radzi: Petnomocnictwo do rachunku bankowego, http://www.nie pelnosprawni.pl/ledge/x/43447.

Koźliński T., 2010, Wykluczenie płatnicze w Polsce i innych krajach UE, http://www.nbp.pl/ systemplatniczy/wykluczeniefinansowe/download/wykluczenie_platnicze_w_polsce_i_innych _krajach_ue.pdf.

Koźliński T., 2013, Zwyczaje płatnicze Polaków, Narodowy Bank Polski, Departament Systemu Płatniczego.

Maciejasz-Świątkiewicz M., 2013, Wykluczenie finansowe i narzędzia jego ograniczania, „Studia i Monografie", nr 488, Uniwersytet Opolski, Opole.

Narodowy Bank Polski, 2003, Bank dostępny. Dostosowanie polskich banków do potrzeb osób niepelnosprawnych i starszych, Wydawnictwo NBP i Stowarzyszenie Otwarte Drzwi, Warszawa.

Ploch L., 2009, W kręgu kultury osób niepetnosprawnych, [w:] Udziat osób niepetnosprawnych $w$ życiu społecznym, kulturowym oraz politycznym, „Socius” Polsko-niemieckie pismo o osobach z niepełnosprawnościami, $\mathrm{nr} 3$.

Rezolucja Zgromadzenia Ogólnego ONZ A/RES?61/106 z dnia 13 grudnia 2006 r., Konwencja Praw Osób Niepełnosprawnych.

Rzecznik Praw Obywatelskich, 2011, Dostępność infrastruktury publicznej dla osób z niepetnosprawnością. Analiza i zalecenia, Biuletyn Rzecznika Praw Obywatelskich Zasada równego traktowania. Prawo i praktyka, Warszawa.

Samcik M., 2013, Na dywanik za to, że nie wciagnąeś klientowi kitu? Tak banki „motywuja” pracowników, http://samcik.blox.pl/2013/04/Na-dywanik-za-to-ze-nie-wcisnales-klientowikitu.html. 
Szreniawska M., 2012, Znaczenie ratyfikacji konwencji o Prawach Osób Niepetnosprawnych, „Niepełnosprawność - Zagadnienia, Problemy, Rozwiązania”, nr III (4), PFRON.

Uchwała Sejmu Rzeczypospolitej Polskiej z dnia 1 sierpnia 1997 r. Karta Praw Osób Niepełnosprawnych, M.P. 1997, nr 50, poz. 475.

Ustawa z dnia 27 sierpnia 1997 r. o rehabilitacji zawodowej i społecznej oraz zatrudnianiu osób niepełnosprawnych, Dz.U. 2010, nr 226, poz. 1475 ze zm.

Warchlewska A., 2015a, Bariery dostępu do obrotu bezgotówkowego na przyktadzie pokolenia 55+, [w:] B. Borusiak, K. Pająk (red.), Nowe wyzwania gospodarcze a problemy zarzadcze w przedsiębiorstwie, $\mathrm{CeDeWu}$, Warszawa.

Warchlewska A., 2015b, Wykluczenie finansowe jako wyzwanie dla sektora bankowego (na przyktadzie aglomeracji poznańskiej), rozprawa doktorska, promotor: prof. dr hab. Alfred Janc, dostęp w Bibliotece UEP, Poznań.

The World Bank, 2014, Financial Inclusion Data/Global Findex, http://datatopics. worldbank.org/financialinclusion/country/poland

Zboroń H., 2004, Koncepcja sprawiedliwości J. Rawlsa, [w:] B. Pogonowska (red.), Elementy etyki gospodarki rynkowej, PWE, Warszawa.

ZBP, 2013, Kodeks etyki bankowej (Zasady dobrej praktyki bankowej), https://zbp.pl/public/repo zytorium/dla_konsumentow/rekomendacje/KEB_final_WZ.pdf.

ZBP, 2014, Dobre praktyki obstugi osób z niepetnosprawnościami przez banki, https://zbp.pl/dlakonsumentow/obsluga-osob-z-niepelnosprawnosciami.

ZBP, 2016a, List skierowany do Prezesów Zarząów Banków i Członków Zwiąku Banków Polskich, Warszawa 19 kwietnia 2016 r., https://zbp.pl/public/repozytorium/dla_bankow/news letter/2016_kwiecien/Zacznik_15.pdf.

ZBP, 2016b, Związek Banków Polskich pomaga w poprawie jakości obstugi osób z niepetnosprawnościami, http://instytucjaroku.pl/?p=968.

\title{
DISABILITY AND THE THREAT OF FINANCIAL EXCLUSION
}

\begin{abstract}
The purpose of this paper is to diagnose the problem of financial exclusion among people with disabilities. The subject of this study is to present the activities of the banking sector aimed at equalizing the chances of access to banking services and critically analyzing them. The situation of people with disabilities and the essence of financial exclusion are presented in the regulations and activities of the Polish Bank Association. The source of literature was the basis for the analysis and the results of own research, which allowed to indicate further directions of research. The structure of paper is subordinate to the research goal.
\end{abstract}

Keywords: financial exclusion, people with disabilities, human rights, good banking practices, banking sector. 